\title{
5 The constitution of neoliberal governmentality from early neoclassical economics to public choice theory
}

\author{
Ceyhun Gürkan
}

\section{Introduction}

Michel Foucault, a true polymath within the humanities and social sciences, provides a fertile and unprecedented ground for a new critical understanding of neoliberal governmentality as the present form of global power in its relation to neoclassical economics. Defying the usual academic specializations and disciplinary divides, his work opens up new ways of approaching politics and economics. Foucault demonstrates how economics played a crucial role in the constitution of classical liberal and, in turn, neoliberal governmentality. Foucault's work also helps us understand how economics in the late 19th century became expert knowledge that laid the foundation for neoliberal governmentality, a 'norm imposing' power modality and 'normative political reason' (Brown, 2015; Dardot \& Laval, 2013). His analysis of economics as part and parcel of the (neo)liberal governmentality rests on the particular conception of power. Foucault (2007), identifying three forms of power (sovereignty, discipline, security management), shows particularly how economics played a decisive role in the transition from the disciplinary mode of power regulated by police to the security-management modality of power. He also presents a rigorous method and analysis as well as a history of government to analyze this critical role of economics around its three interrelated dimensions: knowledge, power/government, and ethics. In doing so, Foucault presents us with a historical, methodological, and analytical framework to elaborate on the evolution of modern economic analysis in its relation to (neo)liberal power. However, one of the missing points in Foucault's work is the absence of the analysis of public choice theory as part of neoliberal governmentality. Another one is a complete analysis of the relationship between early neoclassical economics and the subsequent neoliberal governmentality, with a focus on the specific power modality of security management.

Neoclassical economics was born out of the so-called marginalist revolution in economics in the late 19th century and public choice theory developed after 1940. Foucault (2008) examines, to a degree, how liberal governmentality based on classical political economy underwent a colossal transformation over 
the late 19th century, but he is much more focused on the role of 20th-century neoliberal ideas in this revolution crafting a new political reason against Keynesian politics and economics. Nevertheless, he refers very little to early neoclassical economics, and public choice theory is left completely unnoticed in his account. Given that neoclassical economics with its early and late versions (e.g., new consensus in macroeconomics, behavioral economics, new institutional economics, etc.) and public choice theory are the hegemonic knowledge of economic analysis, discourse, and practice that govern and control the teaching of economics on a micro level (Zuidhof, 2014) and the administration of the state at a macro level, an attempt at incorporating early neoclassical economics and public choice theory into Foucault's history of neoliberal governmentality will be helpful for conceiving the governmental actuality of neoliberalism around its current effects and phenomena.

For Foucault, (neo)liberal governmentality is not reducible to economics and, no less, economic policies. And yet, economics as "knowledge-power" (Foucault, 2008: 19) has always been lateral to (neo)liberal power and governmentality. This being so, neoclassical economics and public choice theory are not to be understood simply as scientific knowledge analyzing the functioning of the capitalist market economy at micro and macro levels. Given their overreach to non-economic relations, spheres, and structures through the application of economic knowledge to the social realm, both theoretical bodies build up and disseminate a specific normative social and political rationality. Following Foucault's analytics and historical survey into governmentality, the particular question to be addressed is how the marginalist turn in economics and later public choice theory, which takes its starting point from Knut Wicksell's neoclassical economics (Buchanan, 1987; Wicksell, 1958), have reformulated the governmental reason of classical political economy by modifying especially its moral aspects and its articulation with different forms of power (i.e., sovereignty, discipline, and security management). In studies of Foucault's analytics of power and governmentality, the place of early neoclassical economics and public choice theory are largely left untouched or underevaluated, except for a few studies (Amariglio, 1988, 1990; Birken, 1990; de Lima, 2019; Gürkan, 2016; Olssen, 2018). The present chapter takes a step towards filling this gap and aims at contributing to the studies of Foucault and governmentality. Before going into this deeply, the problem and method concerning the power and influence of economics over the social and political life will be specified referring to James Buchanan, the founding father of public choice theory.

\section{Problem and method}

With the neoliberal revolution throughout the 1980s, Buchanan and public choice theory became influential on governments as they started reforming their policies, organizations, and administrative and political reason. During the post-World War II period, Keynesian theory and policies played an essential role in guiding the economy and public policies. This also holds true for its 
guiding power in governing public reason about socio-economic matters. The rise of protest movements in the West during the late 1960s was in some respects directed against the disciplinary formation of society under the auspices of the bureaucratic control system that the Keynesian central planning economic model entailed to achieve the aims of full employment and sustainable mass demand that induces investment. This model based on the bureaucratic welfare state was, as Richard Sennett (2006: 27-37) defines, a Weberian 'social capitalism' that created an 'iron cage' because of its highly functional and hierarchical structure despite its certain democratic and progressive aspects. Alongside the new trends in left politics at that time, public choice and monetarism strove to increase their intellectual power of influence and significance for guiding the struggles of masses for freedom vis-à-vis the increasing comprehensive state actions. As Keynesianism was becoming a "common enemy" (Foucault, 2008: 79) at the diverse poles of the political spectrum, public choice scholars took on a political task and action in theory and practice. Public choice theory and its supporters set down the essential principals for guiding the public reason through neoliberal economics and provided an operational framework for economists and politicians as they sought to make new formulations to conduct the social, political, and economic course of movements. Buchanan himself got involved in public debates as part of the public choice school's political mission for promoting normative political economics to guide political and public debates. He occasionally participated in the meetings of the Joint Economic Committee of the US Congress founded in 1946 and expressed his thoughts on public finance and political issues. Buchanan also took a position against the student protests endorsed by left academics and supported tax-protest movements in the 1970s (Brennan \& Buchanan, 2000). During the course of social movements in the 1960s and 1970s, Buchanan's approach to politics and economics changed from a libertarian attitude against the state towards embracing strict regulations by means of state authority (Fleury \& Marciano, 2018). His aim was to take control of the social unrest against capitalism and reformulate a new way of the security of the market, which explains his support of Reagan's conservatism and neoliberal policies.

Buchanan produced considerable volumes of books and articles on public choice theory and constitutional political economy. His analysis of modern society has economic, political, fiscal, and normative-ethical dimensions. It is economic because his theory is concerned with overcoming the crisis of economics by redirecting it on the theoretical course of subjective choice (Buchanan, 1981, 1999) and the will of individualistic freedom. Buchanan's analysis $(1964,1975,1987)$ is normative and political because it aims at sharpening the critique of the state/political market and the economic/fiscal course of affairs that make a case for the Leviathan form of state. Buchanan's theory deals mainly with fiscal policies because he believes that public finance as a science and art of government guides the collective and individual choices of public goods in a market environment and as such lies at the center of politics. Buchanan assigns a critical and defining role to political economists in guiding 
the public reason towards an ideal society he imagines. As such, in Buchanan's setup politics and economics have two dimensions: positive and normative. On the positive side, he sets out to explain scientifically the actual course of economic and political events and developments. On the normative side, from a constitutionalist political economy perspective, he aims at guiding the governmental reason of state as well as the behavior of individuals as they inveigh against the state on the way towards making a new social contract. Finally, Buchanan's public choice theory $(1978,1988)$ has a strong ethical dimension, which has received less attention, because it aims to construct and govern the moral attitudes, behaviors, and subjectivities of individuals in accordance with the rules of the market that emerge out of the rational expectations of individuals and set limits to the state. Buchanan (2008: 472-474) in his recent work turned to Kant's moral philosophy and called for a 'deontological turn' in political economy as a way to govern the conducts and choices of individuals. Buchanan's formulation of internal governmentality of subjects for the constitution of the market society can be best understood within the framework of Foucault's analytics of power and governmentality, which can establish a clear link between the inner logic of the theory and its performative power shaping the reality around their intersectional ties and disparities.

Within liberalism, government through economy can be carried out by making use of economics in two ways: economics as expert knowledge or economics as a means of strengthening individual empowerment. Buchanan sides with the latter and advances an economic and ethical critique of the first model. In doing so, his theory becomes committed to building a certain governmental reason for the state and the acts of individuals. But the vector of governmental relations does not originate from the state, directing itself towards individuals; it is quite the reverse due to its comparatively low costs of government within society. The liberal model of government of the public and individuals has two dimensions. The first includes the interactions between individuals as part of the population under the governmental authority informed by market rules, and the second is the internal governmentality of morality imposing certain restrictions on acts, which means in-depth government through selfgovernment. Buchanan has developed public choice theory to shape this multilayered governmentality through the economics-based intelligibility of politics and, no less, ethics thereby laying the foundation for the government of the state and individuals without making a break between the two.

Buchanan's public choice theory is highly interdisciplinary and has several aims at micro and macro levels. To bring them together and develop a comprehensive analysis of this theory, a unifying analytical framework and method are needed. Foucault's nominalism, discourse analysis, and analytics of power/ government present us with such an analytical and methodological framework. Foucault's overall work sees things and events in their historical course within a triangle, the corners of which consist of knowledge, power/government, and ethics. Knowledge here does not only stem from the scientific production of savants but is something that grows in relation to everyday experiences in 
micro and macro domains of social life. Knowledge reaches its true meaning when constituting the truth and shaping the governmental reason that guides power relations all over society. Then knowledge becomes 'knowledge-power'. To see theories not as scientific knowledge but, through Foucault's prism, as part of 'knowledge-power' that has a performative, constitutive, and concrete practical influence on social reality shows us the relation of knowledge, power, and ethics. Foucault, paying attention to the history of economics around these three dimensions, identifies the constitutive role of economics in shaping the governmental reason of liberalism and neoliberalism. In his words:

Economics is a type of knowledge (savoir), a mode of knowledge (connaissance) which those who govern must take into account . . Economics is a science lateral to the art of governing. One must govern with economics, one must govern alongside economists, one must govern by listening to the economists.

(Foucault, 2008: 286)

Foucault adds, however, that governmental rationality itself is not an entire derivative of economics and cannot be reducible to it. Government, an ensemble of rationalities, is much more than what economists say, but it is impossible to govern without economics in (neo)liberalism. Taking inspiration from this argument, the following sections characterize economics as public science and inextricable part of the art of government, arguing that the governmental attribute of economics is congenital (since its birth back in the ancient times was seen from the concept of oikonomia - the management of household). Therefore, the character of economics as public science and its practical influence on social life can be put by focusing on the notion of government. It is Foucault's merit that we can take up the history of economics as part of the history of government, which allows us to turn this historical account into analytics from a socio-economic perspective.

\section{Neoclassical economics as the foundation of neoliberal governmentality}

In their book Economics: Marxian versus Neoclassical (1987), Richard Wolff and Stephen Resnick explain that the criticism of neoclassical economics cannot be a narrow-scope and finalized critique. According to them, neoclassical economics is not simply an economic doctrine about how the capitalist economy works. It is connected to a general power scheme that shapes the market mechanisms, norms, and rationality in the economic realm as well as culture, habits, and patterns of behavior in the non-economic domains. Resnick and Wolff call for a new critique of neoclassical economics in the neoliberal era because, in Foucauldian terms, they consider neoclassical economics as 'knowledge-power' that programs the state, society, and the conducts of the individual through security management technologies. In this respect, it is necessary to open up 
another way of criticism beyond the traditional disapproval of neoclassical economics based on the critique of its scientific assumptions and method, which tries to elicit that neoclassical economics does not explain reality. Considering that the neoclassical theory, which presumably does not explain reality, has the greatest potential to produce truths to govern and construct reality, a new critique becomes necessary. This critique should first identify the links between neoclassical economics and neoliberal governmentality. As such, a new line of criticism is required for the understanding of the dynamism of symbolic tools, political reason, and self- and social technologies of neoclassical economics that disseminate neoliberal norms and rationality starting from economics education. When the problem is described so, Foucault was the first to approach neoclassical economics from this line of criticism.

The term neoclassical was coined by Thorstein B. Veblen in his 1900 article "The Preconceptions of Economic Science" (Veblen, 1900). Veblen (1898, 1909) argues that neoclassical economics with its reductionist, teleological, non-evolutionary, static, and taxonomic theoretical structure was simply the continuation of classical political economy. Thus, he calls it with the term 'neo-classical', which delineates little and simple modification of classical political economy. What is more, Veblen argues that neoclassical economics relies on the same logic of liberalism, which tries to advance capitalist property relations by promoting the 'absentee ownership' detrimental to the industrial system and material production process which secures the welfare of the society at large. Thus, for Veblen, both classical political economy and neoclassical economics are a kind of 'sabotage' (Veblen, 1994) of the industrial system and welfare of the society. Although aiming in a similar direction by calling them 'knowledge-power', Foucault would not agree in total with Veblen because Foucault recognizes essential differences between the two schools. Foucault discusses these differences in terms of liberal governmentality, not economic theorizing and its ideological biases. However, as already noted, Foucault did not examine and analyze the early neoclassical economics as part of the history of liberal governmentality to the full. "So I will skip two centuries," he writes, "because obviously I do not claim to be able to undertake the overall, general, and continuous history of liberalism from the eighteenth to the twentieth century" (Foucault, 2008: 78). He is mainly concerned with the essentials of the path-breaking shift from classical liberalism of the 18th century to 20th-century neoliberalism. Be that as it may, Foucault's rapid move into the 20th century is a very quick shift that leads to a huge lacuna in his 'history of governmentality' between classical liberal and neoliberal governmentality.

Nevertheless, Foucault is certainly aware that the late 19th century should be distinguished from its early years in terms of the concrete political and economic developments. As the late 19th century witnessed the constitution of welfare capitalism under the increasing fiscal, political, and juridical control of the state, which was all the more fortified during the world wars in the 20th century, the power of laissez-faire economics lost its scientific reliability and credence among the public, thereby falling from the grace as an instrument for 
governmental apparatus and rationality. In effect, the rise of neoclassical economics was a response to the then decaying position of economics. Its critique of classical political economy also aimed to restore the power of economics as expert knowledge against the growing impact of political reason shaped by institutionalist, ethical, and legal views. Against the backdrop of increasing juridification of liberalism, the rise in bureaucratic power and state interventions, neoclassical economics changed the discipline towards highly deductive theorizing through mathematical devices in order to renew the liberal art of governing. Despite its mathematical content and facet stripped of political and social aspects of economic life, early neoclassical economics took its bearing from the search for establishing new liberal governmentality. That is, neoclassical economics started developing a new political reason by slightly mentioning politics and its long-established structural elements and ontological foundations. Towards that aim, it sought to remove the elements in economic theorizing that moved economics away from becoming governmental expert knowledge. As the economics cut off its relationship with the neighboring social science disciplines which once formed the indispensable part of economic thinking, neoclassical economics and rationality developed a new approach to them by either declaring them as representing the non-rational aspect of the social system or inventing new problematizations like the 'Adam Smith problem', which aimed to discard social ethics of sympathy from the liberal art of government (Gürkan, 2016: 135).

Foucault is also well aware of the aforementioned developments that changed the epistemic conditions of the production of knowledge and how they had a bearing on the reshaping of the structure of knowledge. Foucault recognizes that there are differences between the early and late 19th century in terms of the knowledge structure of human sciences. Psychology increased its epistemic power over the social sciences in the wake of Freud's analysis of the unconscious in the last quarter of the century (Foucault, 2011: 27). As a result, psychology became the epistemic mainstay of economics with the marginalist revolution. It should be recalled that Alfred Marshall (1962) at this time regarded biology as having the potential to form a new knowledge system for economics, which was the case for Veblen (1898), who called for a Darwinian evolutionary turn in economics. Like Veblen, Marshall seems to be hesitant about acknowledging the supremacy of psychology over biology when he identifies "economic biology" as "[t]he Mecca of the economist" (Marshall, 1962: xii) to develop a dynamic approach to economics, which refers to the evolutionary thinking in economic theorizing. At the back of the changing structure of the human sciences under the auspices of biology and psychology, Foucault is also conscious of the fact that neoclassical economics made modifications in classical governmental reason in The Birth of Biopolitics as well as its epistemic structure in The Order of Things and then The Archeology of Knowledge. In comparison, the transformation of the governmental reason is clearer than the epistemic modification in Foucault's work. Neoclassical economists radically modified classical liberalism shaped by classical political economy, and what is more, these 
modifications were essential for the development of neoliberal governmentality developed as a 'thought collective' (Mirowski \& Plehwe, 2009) after 1930 and a global art of government in practice after 1980.

Therefore, neoclassical economics stands at a very critical position and juncture in the overall history of liberal governmentality as presented by Foucault, and it is crucial to understand the specificity, reality, and attributes of neoliberal governmentality. Given that marginalist economics in the late 19th century carried out very radical modifications of classical liberalism, it is fair to say that there are not two types of liberal governmentality as Foucault argues. Three stages or types can be distinguished in the history of liberal governmentality: classical liberalism, neoclassical liberalism, and neoliberalism. Classical liberalism was the early liberalism that was still in the domain of the reason of the state configured by police and discipline; neoclassical/neoliberal economics and governmentality together formed 'advanced liberalism' (Rose, 1993). However, Foucault, if not totally, seems to be ignorant of the importance of the late 19th century in terms of political/economic events and theories. As noted, he has a reason for this deliberate neglect. Foucault states that he does not want to be engaged in presenting the entire history of liberal governmentality and prefers to center his focus on the shift from classical liberalism of the 18th century (Smith) and the early 19th century (Ricardo) to neoliberal governmentality of the 20th century. By doing so, Foucault specifies the aspects of neoliberal governmentality. Nevertheless, there remains a huge gap in the history of (neo) liberal governmentality. He little mentions about the first half of the 19th century around Ricardo's political economy, but they are very much rare when it comes to the late 19 th century.

Foucault's approach to early neoclassical economics was a matter of debate between Lawrence Birken (1990) and Jack Amariglio $(1988,1990)$ in the late 1980s. In this debate, the question of marginalism is about its episteme. The authors were the first to ask the position of marginalist economics in Foucault's work. Although their articles are valuable to develop an understanding of Foucault's thoughts on the marginalist turn in economics, this early debate remained in the scope of the question of episteme. This is so because Foucault's analytics of government he developed in his lectures 1977-8 Security, Territory, Population and 1978-9 The Birth of Biopolitics came to be known fully after 2000.

Foucault $(1989,2002)$ used the method of archeology in his early works, and he dealt with long-term epistemic structures of knowledge in unity. $\mathrm{He}$ distinguishes the pre-classical period of episteme based on 'resemblance' before the 16th century from the classical age, which was based on 'representation' and lasted until the end of the 18th century/early 19th century. Afterward, the modern period develops. The modern era in which Man as a finite being is invented is 'the age of Man'. Over the modern era, man evolved into 'human species' from 'mankind' with the effect of human sciences shaped particularly by psychology and biology as well as political economy and historical philology (2007: 78). Man becomes a subject having a biological and psychological 
life (the body, mind, desire), working life, and a historical language. 'Classical political economy' gives weight to the body (physical effort to be disciplined in a panoptical system of control) and (neoclassical) economics to mind and desire. The first sees the body as the physical force; the latter conceives it as a neurological and, to a greater extent, psychological force and being. What is more, Foucault within the scope of the archeological method identifies a critical moment in Ricardo's political economy. Ricardo invented 'finite man' in the modern age of episteme (human sciences) and biopolitics as Kant once did in philosophy by bringing the question of the present into philosophy (Foucault, 1988: 87, 89, 95). In his work Foucault (2011: 27) seems that he does not recognize a critical moment or an immense epistemological break in marginalism, but in an interview with Alain Badiou in 1965 he states that Freud's analysis of the unconscious in late 19th century paved the way for a new turn in human sciences, a kind of "deep archeological transformation". Accordingly, psychology started dominating human sciences. This is the very moment that neoclassical economics emerged as a new science of political economy or economics omitting the political. It is also fair to argue that its rise was the emergence of a new governmental reason. In the light of the archeological method of Foucault, the continuity and discontinuity between classical political economy, particularly Ricardian economics, and neoclassical economics are seen around their epistemic structures and position within the wider episteme of more or less the same modern age in unity. Within the framework of the archeological method, this changing epistemic line between them is less discernible in comparison to their altering governmental logic. The modification of governmental reason is clearer and more severe towards a break.

In terms of the epistemic structure of marginalist economics, it is hard to identify another radical 'epistemic break'. Marginalism was still in continuity with the utilitarian philosophy of classical political economy, but it took a huge step, but not the first, to dismantle the classical governmental and political rationality and modify the general epistemic structure of classical political economy situated in naturalism. The first step was taken by John S. Mill, who still regarded the class structure of society and the labor theory of value as the unit of analysis in economics but brought forward active homo economicus (the rational economic man) as governmental technology that ceases to be part of the natural and exchange-based market economy. With Mill, political economy entered into its age of Man. As Margaret Schabas (2005) shows, marginalism followed and completed Mill's effort of 'denaturalization' of economics by shifting the focus of economics from nature and the reason of nature towards the calculative reasoning of man within a strict hedonistic conception of the existence of human being. The oscillation from nature to the human mentality blended with a strong psychological grounding was a great step to modify the epistemic structure of classical political economy, which makes economics a 'mental science'. As homo economicus in classical political economy is the natural limits of the state intervention, in neoclassical economics the hedonistic economic man becomes "a lightning calculator of pleasures and pains" as Veblen 
(1898: 389) sarcastically criticizes. Shortly after Mill, marginalism developed further this shift towards a complete 'mental science' (Schabas, 2005) in a way to make a break with classical naturalism in terms of more or less active governmental reason based on the human mind, whether in the form of welfareplanning bureaucratic mentality as in the British neoclassical economics, single political leader as in the Italian neoclassical economics, single super-rational homo economicus in the market behaving according to alternative costs as in the Austrian neoclassical economics, or rational civil collective action in the political market as in the Swedish neoclassical economics, which is close to Buchanan's neoliberal economics (Kayaalp, 2004). So, we observe three types of homo economicus in the history of liberal governmentality: first, 'untouchable' homo economicus in classical political economy who specifies the natural border of the state under the rule of an 'invisible hand'; second, the neoclassical homo economicus as an absolute mental being who is solely directed by desires and self-interests; third, the neoliberal homo economicus as an acting agent who responds to the environment which is to be constructed in an economization process. Under the present condition of authoritarian neoliberalism, Wendy Brown (2015: 213) mentions another type of the neoliberal homo economicus to be sacrificed for the market economy, particularly for the sake of the financial industry.

As such, the specificity of marginalism in the late 19th century lies in a modification of the epistemological structure of classical political economy and a radical change close to a break in terms of governmental reason, which laid the foundations for neoliberalism. As classical political economy evolved from Smith, Ricardo, and Mill towards neoclassical economics, the marginalist turn made clearer in-depth modifications of the previous forms and structure of knowledge and political reason. Nature/physics and the working man were replaced by psychology and the desiring man within the same age of Man. At that time, biology was seen by radical and critical evolutionary economists like Veblen as the alternative approach against the neoclassical economics, having the potential to recast the historical aspect of the former in a dynamic way as well as having an alternative governmental reason. However, modern biology based on the Darwinian evolutionary theory, then, could not establish another successful rupture in epistemic structure and governmentality within economics as 'knowledge-power', which, however, is crucial today to envisage the alternative against the epistemic and governmental matrix of neoclassical/ neoliberal economics.

When Foucault turns to genealogy, power, and government, he details this great transformation in the late 19th century more but does not specifically make it part of the history of liberal governmentality. And yet, when we look at his mentions about marginalism and early neoclassical economists, we see that Foucault is well aware of how important it is for neoliberal governmentality because marginalism, as noted, carried out radical modifications in the classical liberal governmentality. And this is not about the discarding of the labor theory of value by the utility theory of value. There are other radical modifications by 
early neoclassical economics. Accordingly, we are moving away from classical naturalism towards the human agency and radical humanism around the question of calculative human reason against the reason of nature and reason of the state in which classical political economy was placed. Thus it can be argued that marginalism and classical political economy were situated in more or less the same episteme but produced different governmentalities. The relationship between episteme (long-term knowledge structure) and governmentality reason (political power) is another issue to be taken up thoroughly, but it is fair to say that the 19th century saw two radically different governmental rationalities.

Foucault (2008: 61-62, 118-121, 219ff) discusses neoclassical modifications that laid the foundations of neoliberal governmentality over the period from 1870 to 1930 in a dispersed manner, but their main context is the shift from classical liberal governmentality to neoliberal governmentality. He accords critical importance to early neoclassical economics in three shifts: the first shift is the reconception of homo economicus by neoliberal governmentality as a competitive and consumer subject rather than a subject of equal exchange and material production. The second shift from classical liberal to neoliberal governmentality occurs in the context of the move from the naturalist conception of the market to the constructivist and 'active governmentality' that considers the market as a field of permanent intervention and a field to be constructed around the competition principle, which, in turn, becomes the model and benchmark of all governmental reason and practice. The third shift is from the classical conception of labor around the idea of labor power, which refers to the effort of the physical body, to the neoliberal conception of the worker as a self-enterprise or entrepreneur. So, the meaning of work, worker, and wage changes, and they are not characterized anymore by antagonistic social relations, working time, and material conditions. They acquire their meaning through human mentality, subjective point of view, and individuals' rational choices.

In neoliberal governmentality, a normative political project, we see a constructivist and active government that generalizes the economic rationality and practices across the society at large in which individuals as competitive selfenterprises unfold. This entire story and discourse about the economization of life, constructivist governmentality, and competitive self-entrepreneurial agency began with the marginalist revolution in economics. In this sense, although it is still a debatable issue to argue that it was a radical epistemological break in the widest sense, one thing is certain - there is a radical transformation towards a clear-cut rupture materialized by early marginalist economics in terms of governmentality, which was later perfected by neoliberalism over time up until the present.

To recap, neoclassical economics shifted the field of analysis of economic theory from production to consumption. In doing so, neoclassical economics considers competition, not the equal exchange, as an organizing principle of the economy and society. It has made human behavior an object of economic study. As such, it discovers the entrepreneur as a singular subject. But it does not understand the mechanics of the entrepreneur's movement. 
Neoclassical economics mostly understands the entrepreneurial subject as a natural being within the static relations of material conditions of production and consumption. Joseph Schumpeter (1950, 1961) develops this discovery in capitalism from a sociological and historical point of view. And Schumpeter conceptualizes the entrepreneur as an extraordinary subject, almost like a hero. Neoliberalism modifies this conception of hero-entrepreneurship into mass-entrepreneurship in a way to construct everyone as a single entrepreneur and, as such, to form an entrepreneurial society under permanent and active governmentality. Thus, there are continuities and discontinuities between neoclassical economics (early marginalism, the Schumpeterian modification, and established orthodoxy in the 1920s) and neoliberal governmentality (ordoliberalism, American anarcho-capitalist neoliberalism, and Austrian neoliberalism). Public choice theory is another type of neoliberal governmentality that has been carved out within these continuities, discontinuities, and modifications, which Foucault completely left untouched.

\section{From neoclassical to neoliberal governmentality: Buchanan and public choice theory}

Foucault's study of neoliberalism is centered on German ordoliberalism and the American Chicago School. Foucault was not interested in the theory of public choice, just as he kept early neoclassical economics out of the history of liberal governmentality. There is no reference to public choice theory in his work on neoliberal governmentality. However, if Foucault had seen the economic and political situation of neoliberalism today, and looked at how the behaviors and subjectivities are shaped in the private and social/political sphere within the current neoliberal structure and how the state reason is formed, he would have given to public choice theory a certain place in his work on neoliberal governmentality.

Public choice theory is in the focus of critical theory today. The main reasons are the following: first of all, this theory is dominant in economic theory and politics. It is the essential inspiration for the new public management model and neoliberal governance based on using economics as a business form of expert knowledge for constructing the wide-ranging performative indicators, although Buchanan would not agree with the overlap of his theory with the model vis-à-vis the expansion of the bureaucracy under the model (Knafo, 2019: 4-7), which is an interesting case to see the articulation of a theory with the reality it is opposed to. Public choice theory opposes representative democracy, especially the democratic model of the Keynesian welfare state. It sees faulty public policies and democratic mechanisms as the cause of economic crises. Collective politics, being inherently evil, creates the conditions for the political market of rent-seeking behaviors. The idea of public interest is impossible, and this idea should not be enforced. The idea of public interest and democratic collective policy mechanisms should be abandoned. The state should be restructured according to the principles of competition and entrepreneurship. 
But this would not mean to weaken the reduction of the state force. The political and economic order should not be left to the idea of spontaneous order as Hayek argued. The state, which should be formed in accordance with neoliberalism, should construct the market and the appropriate human subjectivity and patterns of behavior (Olssen, 2018). In this respect, the political sphere and subjectivity should be constructed according to the economy. In other words, homo politicus representing the collective politics around the public interest should be eliminated by homo economicus (Brown, 2015). Public choice theory is a branch of 'economic imperialism' whose core assumptions are 'selfinterest', 'market exchange', and 'individualism' (Udehn, 1996). As such, it is an application of economics to non-economic fields through these assumptions, in which context it develops normative constructivist policies through which the economy is constructed as a 'game'. It supports both economization and constructivism; in this sense public choice theory should be taken into the analysis of governmentality to reveal its political rationality and governmental technologies of the social and the self.

Based on the elucidations and literature review back in section 2, when it is understood as an economic theory, public choice theory is defined as a branch of political economy in the form of the economics of politics. When it is seen at the level of abstraction around its assumptions, the focus of public choice theory is the question of how the content and volume of public services/goods in the democratic market society are determined collectively and how they are realized simultaneously. But the theory is much more than an economic theory. Public choice theory has certain normative aspirations about human subjectivities and deserves attention from a governmental perspective. The theory connects the existence, functioning, and critique of public authorities and the structure of publicity to radical individualism. What is more, it attributes the constitutional construction of the political sphere to the rational choices and interests of individuals who produce the rules of economy and the institutions. At this point, establishing a legitimate and systematic neoliberal bond between the state/politics and the individual, the transformation of rules and institutions in accordance with neoliberal governmentality becomes a task for public choice theory.

The political task of the theory is to present an explanation of not only the complex political structure that arises from interpersonal interactions but also the neoliberal construction of the structure and subject. Normatively, for Buchanan, the task of the constitutional political economist is to assist individuals as citizens who want to control their social order while continuing to seek the rules of the political game that will best serve their purposes. The transformation of individuals' behaviors and institutions can be accomplished by the existence of a comprehensive new political economy that focuses and works on human action, not social engineering as adopted by the Keynesian planning model. Public choice theory aims to make the fundamental ideas of the market economy operational in practice to maintain the freedom and welfare of autonomous individuals who create the values of the political and social 
complex, which derives from the interrelation of human actions. According to this normative view, it is essential to focus not on single human action but instead on behaviors between one another in the political and social structure, which should be dissociated from representative democracy and collective politics.

Since representative democracy does not prevent the expansion of the state and does not have a mechanism to regulate personal interests, it encourages the reproduction of rent-seeking behaviors in a political structure. Public choice theory has two solutions, one being political and the other ethical. Since politics is not necessarily concerned with the public in Buchanan's setup, it can expand the state in line with the economic interests realized in the realm of politics or the political market. At the constitutional level, it is necessary to formulate rules restricting the state, which future governments must obey. These rules are designed compliant with the rational expectations of individuals about the future. As these rules operate, the mutual play of personal interests can simultaneously ensure equilibrium in the market (invisible hand) and the preservation of stability and protection of individual freedoms in public and collective life. Foucault mentions the rising of "party governmentality" (Foucault, 2008: 191) against the state governmentality in the 20th century. In effect, Buchanan's theory of voting and rules is directed against 'party governmentality' that expands the scope of the state budget in close relation with the mass and public interest. Buchanan tries to build up strict individualistic governmentality to restrict 'party governmentality', which shifts his focus to ethics. This also demonstrates that neoliberal governmentality relies on a highly interdisciplinary economic theory in which discipline acquires its true meaning in the sense of the internal disciplining of individuals and interrelations.

The second solution is at an ethical and normative level, and this precisely defines the internal governmentality of public choice theory that seeks to construct a specific subjectivity. Buchanan's theory is known for its generalization of economics, but its constructivist nature is less emphasized. This is more about its normative character that employs external and internal constructivist forces. The external force is the small but strong state, the other being what Foucault would describe as 'the technology of the self'. The latter tries to establish disciplinary power in the subjectivity as permanent internal governmentality of individuals in a way to set the limits subjects cannot surpass in their civic life. For self-government and internal regulation of individuals according to the market rules, Buchanan (2008) in a recent text considers Kant with an eye to incorporating the Kantian deontological ethics as a self-technology and the way of internal limitations of the self for establishing the disciplinary power and morality into the neoliberal governmentality in defense of the market economy, as the ordoliberals once did to establish the market economy as the sole and true moral way of social and civic life. However, the present mode of liberal self-government includes not only the Kantian morality and imperatives to ensure "conduct of conducts" (Foucault, 2007: 389) from within for the market game to play, but also external imperatives that are seen clearly from 
the politics of austerity, which turns self-government to self-sacrifice under the sway of the populist and authoritarian neoliberalism.

\section{Conclusion}

Neoclassical economics and the neoclassical-based theory of public choice have been reconsidered in the light of Foucault's analytics and history of government through Foucault's nominalist, archeological, and genealogical method that understands the structure and constitution of social life based on the power of knowledge and interactions of individuals. By elaborating on early neoclassical economics further in Foucault's work in its relation to neoliberal governmentality and filling a gap in Foucault's history of neoliberal governmentality through the analysis of public choice theory, the chapter has also provided a methodological and analytical framework in a historical context for the question of how economics has become the socially diffuse public science of the art of government in (neo)liberalism. The foregoing discussion in the context of public choice theory with a specific focus on Buchanan has shown that the power of economics on public debates relies on its achievement of governmental power that turns it into a public science by constituting a relation between knowledge, power/government, and ethics. Although Buchanan is opposed to the type of economics as expert knowledge, he aims to make the constitutional political economy the public science that is committed to and geared towards developing a constant and daily critique of the state power in the mindset and attitudes of individuals in a neoliberal way, as Foucault describes. On the other side, Foucault's critical attitude against neoliberal capitalism, which has been and is still supported by public choice, exhibits a contrary and opposed disposition through the ethical critique of the Kantian deontology as contemplated by Buchanan for the purpose of setting the insurmountable limits of the market in theory and practice. Foucault's archeological, political, and ethical analytics is helpful not only to analyze the neoliberal complex in its actuality and entirety but also to invent an alternative governmentality through an active critique of our historical presence, thereby taking action in the form of "counterconducts" (Foucault, 2007: 389) for the alternative present and future.

\section{References}

Amariglio, J. (1988). The body, economic discourse, and power: An economist's introduction to Foucault. History of Political Economy, 20(4), 583-613.

Amariglio, J. (1990). Reply to Lawrence Birken. History of Political Economy, 22(3), 562-569.

Birken, L. (1990). Foucault, marginalism, and the history of economic thought: A rejoinder to Amariglio. History of Political Economy, 22(3), 557-562.

Brennan, G. \& Buchanan, J. (2000). The power to tax: Analytical foundations of a fiscal constitution. The collected works of James M. Buchanan, vol. 9. Indianapolis: Liberty Fund.

Brown, W. (2015). Undoing the demos: Neoliberalism's stealth revolution. New York: Zone Books.

Buchanan, J. (1964). What should economists do? Southern Economic Journal, 30(3), 213-222. 
Buchanan, J. (1975). A contractarian paradigm for applying economic theory. The American Economic Review, 65(2), 225-230.

Buchanan, J. (1978). Markets, states, and the extent of morals. The American Economic Review, 68(2), 364-368.

Buchanan, J. (1981). Introduction: L.S.E. cost theory in retrospect. In J. Buchanan \& G. G. Thirlby (eds.), L.S.E. essays on cost (pp. 3-16). New York/London: New York University Press.

Buchanan, J. (1987). The constitution of economic policy. The American Economic Review, 77(3), 243-250.

Buchanan, J. (1988). Contractarian political economy and constitutional interpretation. The American Economic Review, 78(2), 135-139.

Buchanan, J (1999). Cost and choice: An inquiry in economic theory. The collected works of James M. Buchanan, vol. 6. Indianapolis: Liberty Fund.

Buchanan, J. (2008). In search of homonculus politicus. Public Choice, 137, 469-474.

Dardot, P. \& Laval, C. (2013). The new way of the world: On neoliberal society. London/New York: Verso.

de Lima, I. V. (2019). Foucault on the marginal revolution in economics: Language and the Cartesian Legacy. Review of Political Economy, 31(1), 60-74.

Fleury, J.-B. \& Marciano, A. (2018). The making of a constitutionalist: James Buchanan on education. History of Political Economy, 50(3), 511-548.

Foucault, M. (1988). The art of the telling the truth. In L. D. Kritzman (ed.), Politics, philosophy, culture: Interviews and other writings 1977-1984 (pp. 86-95). London: Routledge.

Foucault, M. (1989). The order of things: An archeology of the social sciences. London/New York: Routledge.

Foucault, M. (2002). Archaeology of knowledge. London/New York: Routledge.

Foucault, M. (2007). Security, territory, population, Lectures at the Collège de France 1977-1978. New York: Palgrave Macmillan.

Foucault, M. (2008). The birth of biopolitics, Lectures at the Collège de France 1978-1979. New York: Palgrave Macmillan.

Foucault, M. (2011). Felsefe ve psikoloji (Philosophy and psychology). In I. Ergüden (ed.), Felsefe sahnesi (The scene of philosophy) (pp. 19-30). İstanbul: Ayrunt1.

Gürkan, C. (2016). The politics of neoclassical economics: Insights from Foucault's history of governmentality. History of Economic Ideas, 24(3), 117-143.

Kayaalp, O. (2004). The national element in the development of fiscal theory. New York: Palgrave-Macmillan.

Knafo, S. (2019). Neoliberalism and the origins of public management. Review of International Political Economy. Published online.

Marshall, A. (1962). Principles of economics. London: Macmillan.

Mirowski, P. \& Plehwe, D. (eds.) (2009). The road from Mont Pèlerin: The making of the neoliberal thought collective. Harvard: Harvard University Press.

Olssen, M. (2018). Neoliberalism and democracy: A Foucauldian perspective on public choice theory, ordoliberalism, and the concept of the public good. In D. Cahill, M. Cooper, M. Konings \& D. Primrose (eds.), The SAGE handbook of neoliberalism (pp. 384396). London: Sage.

Rose, N. (1993). Government, authority and expertise in advanced liberalism. Economy and Society, 22(3), 283-299.

Schabas, M. (2005). The natural origins of economics. Chicago/London: The University of Chicago Press. 
Schumpeter, J. A. (1950). Capitalism, socialism and democracy. New York: Harper \& Brothers Publishers.

Schumpeter, J. A. (1961). The theory of economic development: An inquiry into profits, capital, credit, interest and the business cycle. Cambridge, MA: Harvard University Press.

Sennett, R. (2006). The culture of the new capitalism. New Haven/London: Yale University Press.

Udehn, L. (1996). The limits of public choice: A sociological critique of the economic theory of politics. London: Routledge.

Veblen, T. (1898). Why is economics not an evolutionary science? The Quarterly Journal of Economics, 12(4), 373-397.

Veblen, T. (1900). The preconceptions of economic science. The Quarterly Journal of Economics, $14(2), 240-269$.

Veblen, T. (1909). The limitations of marginal utility. The Journal of Political Economy, 17(9), 620-636.

Veblen, T. (1994). The engineers and the price system. London: Routledge/Thoemmes Press.

Wicksell, K. (1958). A new principle of just taxation. In R. A. Musgrave \& A. T. Peacock (eds.), Classics in the theory of public finance (pp. 72-118). London: MacMillan.

Wolff, R. D. \& Resnick, S. A. (1987). Economics: Marxian versus neoclassical. Baltimore/London: The John Hopkins University Press.

Zuidhof, P.-W. (2014). Thinking like an economist: The neoliberal politics of the economics textbook. Review of Social Economy, 72(2), 157-185. 